\title{
THE LOCAL WISDOM IN JAVANESE THINKING CULTURE WITHIN HANACARAKA PHILOSOPHY
}

\author{
Fitriana Kartika Sari \\ STKIP PGRI Ponorogo \\ email: fitrian.kartikasari@gmail.com
}

\begin{abstract}
(Title: The Local Wisdom In Javanese Thinking Culture Within Hanacaraka Philosophy). Hanacaraka refers to the written language of Javanese, Javanese script. The name is based on the order of the twenty-Javanese-script, which is started by the series of hanacaraka script. This study aims to describe the local wisdom content of Javanese Thinking culture within the philosophical meaning of hanacaraka. This study used a semiotic approach applied to the main data source, namely Serrat Kérata Basa. The results showed that (1) the philosophical meaning of the hanacaraka script was fully equipped with the wisdom of Javanese thinking culture in the form of symbolism and othak-athik mathuk which is supported by deep contemplation which involves all the common senses, including the inner sensitivity; (2) hanacaraka philosophy depicts God creature's (human) circumstances, which is equipped with creation, feeling, and effort; human cannot avoid all God's fate upon them until the end of their life; human conditions that achieve life harmony due to the ability to unify the manifestation of God and human characteristics, which heats up within themselves; human condition which put God's order highly by doing all the orders and avoiding all of His warnings.
\end{abstract}

Keywords: local wisdom, Javanese thinking, Hanacaraka

\section{INTRODUCTION}

Javanese local wisdom is the principal factor of thoughtful thinking which covers then aspects of knowledge, faith, comprehension or understanding, customs, and ethics. Javanese local wisdom guides and underlies Javanese behavioral pattern to God, society, nature, and supernatural being for generations. The Javanese thoughtful thinking is part of philosophical thinking system. Gie (2012:29) stated that philosophy is derived from the Greek word philosophia which means the love for wisdom. Philosophia is rooted from the word philos, philia which means 'love' and sophia means 'wisdom'. Philosophical thinking system is created because human is always eager to know and find the authentic truth for everything. Human tries to seek for the revelating indicator of all mysteries deeply through the use of all the common senses to gain satisfying conclusive answer for their curiosity. Sulaksono (2014: 2) stated that to do philosophy is to think deeply, scientificcally, and responsibly. Furthermore, Herusatoto (2008: 105) explained that to do philosophy is to think using all common senses deeply, responsibly, methodically, systematically, orderly and sequentially in order to reveal a mystery and figure out the general conclusion. Eventually, the pillar of Javanese thoughtful thinking creates a local wisdom that is believed to be the filter and 
control of the destructive cultural dynamic effect for generations. Rais (2017: 47) stated that local wisdom is the local knowledge system own by the society which is based on the self experience and the ancestral guidance for centuries. It is flexible as to overcome local situation and condition to control the direction of the all developing field in society to survive the effect of destructive culture.

The forms of Javanese local wisdom are the thinking culture of othak-athik mathuk and symbolism. Othak-athik mathuk is the manifestation of Javanese philosophical thinking which takes form of a thinking culture frequently applied to interpret all phenomena of life. It can be said that othak-athik mathuk is Javanese-style semiotics. So, othak-athik mathuk which is used as a basis for thinking is not only a matter of speculation. Related to the definition of othak-athik mathuk, Endraswara (2016: 21-22) explained that the tradition of othak-athik mathuk is the Javanese thinking pattern which involves intellectual and emotional quotient as the foundation to culturally analyze everything. Though it is rather speculative, yet is still justifiable and logic. Hence, it is recognized as highly spiritual thinking pattern because it can reveal the phenomena beyond the real world that is impossible for the common thinking tradition to interpret. Thus, the meaning obtained is more valid, rational, and reliable if it is used as wisdom words (pitutur luhur) or guidances to address various phenomena in the future.

Alongside the othak-athik mathuk thinking culture, Javanese local wisdom which is reflected in Javanese daily culture is symbolism culture. Javanese symbolism culture is reflected in all aspects as it forms the symbolic acts. The fact is line with the Javanese life manner, especially the traditional society in the past, which generally states a phenomenon in vague through signs and symbols. Herusatoto (2008: 155) stated that Javanese symbolism forms are so dominant in all daily life aspects; as the real application of their life perception and manner. The symbolic forms are classified into symbolical acts in religion, symbolical acts in tradition, and symbolical acts in art. One of the reflections of the Javanese symbolical act is the creation of Javanese script. Javanese script is one of the tools to actualize the moral teachings related to the Javanese typical life manner which are disguised through symbols and idioms. Therefore, the symbols within the orderly sequence of Javanese script is interesting for further study.

Javanese scripts are the Javanese ancient written literary cultural heritage of the tribe which lives on the central and east part of Java Island and has Central Java, East Java, and Yogyakarta as its cultural-orientated regions. The main literal function of Javanese script is the literate function which is highly relevant to the written culture as the idea generators or documentary means of a phenomenon. As Sulaksono (2014: 74) said, the main function of Javanese script is the literary function, the means to express the Javanese' sense and feeling in written form. The paradigm of the literary function of the Javanese script is still deeply-rooted. Most of the researches withinthe last twenty years were the research on increasing the motivation and mastery of Javanese script literary function. However, there was a scientific forum which specially discuss about Javanese script and the meaningful implication within. The forum was Seminar Nasional Pengkajian Ha-na-cara-ka (National Seminar of Ha-na-ca-ra-ka Study) which was held on 15-16 April 1994 in Yogyakarta through the cooperation of Balai Kajian Sejarah and Nilai Tradisional 
(Jarahnitra) Yogyakarta with Lembaga Javanologi Yayasan Panunggalan Yogyakarta. The papers on Javanese scripts' meaning in the seminar were Makna Ha-na-ca-ra-ka; Tinjauan dari Segi Filsafat Sufisme (Ardani, 1994), Ha na ca ra ka Pemahaman Total Integral Makna Kehidupan (Supadjar, 1994), Pengkajian Hanacaraka dari Segi Sastra (Darusuprapta, 1994). There was also some researches on hanacaraka philosophy, as the research by Suwardi (1996) which was focused on the applicative study of othak-athik mathuk principle to interpret Javanese script philosophy. Riyadi's reseach (2005) focused on the study of Javanese philosophical meaning in Serrat Sastra Harjendra by Tan KhoenSwie was related with the life perfection teaching. The next is Ekowati's research (2012) which focused to acquaint the Javanese script as the symbols of Javanese civilization, the symbols which contain historical, philosophical values, and advantages. In addition, Awalin's research (2017) was focused on the study of Javanese script's philosophical meaning in relation to the theology concept and human-God relationship. These studies have proven that Javanese script or hanacaraka is a product of Javanese thinking culture wisdom that is full of philosophical meaning.

Javanese local thinking culture implied in hanacaraka philosophy becomes the evidence that Javanese has had the local culture. Those local cultures become the identity and controller from the negative consequences of cultural dynamism. This article aims to describe the Javanese local wisdom of thinking culture within hanacaraka philosophy which is varied to be noted by people in general. The results of this research are aimed to motivate other researcher, especially the Javanese researcher to preserve and study notable values within hanacaraka philosophy. Furthermore, the results of this research are aimed to be useful for the Javanese teacher to enrich the materials about Javanese script. The presentation of Javanese script materials are expected to be more than introduction to the shape of the script but also on its philosophical meaning.

\section{METHOD}

This was a descriptive qualitative research which used semiotics approach and documentary analysis technique. Semiotics approach was used to study the implied local wisdom of Javanese thinking culture within the philosophy hanacaraka script. The object of this research was specifically on the philosophical meaning hanacaraka script in Serat Kérata Basa. The manuscript is the collection of Radyapustaka Museum, Surakarta, which is coded as SMP-RP 300. Sêrat Kérata Basa is a 27-pages-long literary work in form of gancaran or prose and written on Javanese scripts. It used modern Javanese language and mixed with some words from Kawi languages, Sanskrits, and Arabic. The Serat does not mention the author's name, it only mentions that it was written on August 14th, 1895 in Surakarta with red and black ink $21 \times 16,7 \mathrm{~cm}$ paper. Sêrat Kérata Basa includes the teachings of life which are related to attitude and procedure to achieve the true form life as God's being to become an excellent being. This serat also describes the human characteristics which are symbolized through twenty Javanese script started by $h a$ up to $n g a$ script and sapta swara which consists of murda script of A, I, U, E, O, alongside the rê dan lê script. Therefore, the researcher used purposive sampling to take representative sample of local wisdom of Javanese thinking culture within hanacaraka philosophy. 
Table 1 Finding on the Local Wisdom in Javanese Thinking Culture within Hanacaraka Philosophy

\begin{tabular}{|c|c|c|}
\hline No & Script & Finding on the Local Wisdom in Javanese Thinking Culture \\
\hline 1. & $H a$ & $\begin{array}{l}\text { Symbol and othak athik mathuk which describe } \\
\text { human characteristics that have high luck. }\end{array}$ \\
\hline 2. & $\mathrm{Na}$ & $\begin{array}{l}\text { Simbol dan othak athik mathuk which depicts five human developmental stages during } \\
\text { pregnancy which is symbolized by the five lights of precious stones. }\end{array}$ \\
\hline 3. & $\mathrm{Ca}$ & $\begin{array}{l}\text { Symbol and othak athik mathuk which depicts human wrath. This type of desire is } \\
\text { easily adhered as the typical characteristics of the previous generation, thus parents } \\
\text { should be careful to prepare them from now on. }\end{array}$ \\
\hline 4. & $R a$ & $\begin{array}{l}\text { Symbol and othak athik mathuk which depicts God presences in all life aspects, } \\
\text { although human cannot see it directly. As a human being, we can only feel God's } \\
\text { presences through the dinamic fate we see and undergo. }\end{array}$ \\
\hline 5. & $K a$ & $\begin{array}{l}\text { Symbol and othak athik mathuk which } \\
\text { describe the characteristics of intelligent humans. }\end{array}$ \\
\hline 6. & $D a$ & $\begin{array}{l}\text { Symbol and othak athik mathuk which describe five living means, body, desire or need, } \\
\text { breath, soul, and energy. }\end{array}$ \\
\hline 7. & $T a$ & Symbol and othak athik mathuk which depicts human compliance to accept God's fate. \\
\hline 8. & $S a$ & Symbol and othak athik mathuk which depicts the human weakness. \\
\hline 9. & $W a$ & $\begin{array}{l}\text { Symbol and othak athik mathuk which depicts the acts conducted by human to abolish } \\
\text { suffering. }\end{array}$ \\
\hline 10 . & $L a$ & $\begin{array}{l}\text { Symbol and othak athik mathuk which depicts state of nupus. Nupus is the type of } \\
\text { breath which controls feelings. }\end{array}$ \\
\hline 11. & $P a$ & $\begin{array}{l}\text { Symbol and othak athik mathuk which depicts destructive human conditions, i.e. } \\
\text { having negative attitude to others, having obstinate character, being insensitive and } \\
\text { disrespectful to others, being rude, and conducting vices. }\end{array}$ \\
\hline 12. & Dha & $\begin{array}{l}\text { Symbol and othak athik mathuk which human creation acts derived from all driven } \\
\text { attributes called as napas, anpas, tannapas, nupus. }\end{array}$ \\
\hline 13. & $J a$ & $\begin{array}{l}\text { Symbol and othak athik mathuk which depicts five human desires which put human } \\
\text { into conflict. }\end{array}$ \\
\hline 14. & $Y a$ & $\begin{array}{l}\text { Symbol and othak athik mathuk which depicts five human desires such as lawwamah, } \\
\text { amarah, supiyah, muthmainnah, and mulhamah. }\end{array}$ \\
\hline 15. & Nya & $\begin{array}{l}\text { Symbol and othak athik mathuk desires things which become the source of the } \\
\text { problem. }\end{array}$ \\
\hline 16. & $M a$ & $\begin{array}{l}\text { Symbol and othak athik mathuk which depicts five human desires, such as mutmainnah, } \\
\text { amarah, supiyah, radhiah, and mardhiah. }\end{array}$ \\
\hline 17. & $G a$ & $\begin{array}{l}\text { Symbol and othak athik mathuk which depicts five things that abrupt human } \\
\text { peacefulness. }\end{array}$ \\
\hline 18. & $B a$ & Symbol and othak athik mathuk which depicts five human visions. \\
\hline 19. & Tha & $\begin{array}{l}\text { Symbol and othak athik mathuk which depicts five human desires, amarah (wrath), } \\
\text { lawwamah, supiyah, muthmainnah, mulhamah. }\end{array}$ \\
\hline 20 . & $N g a$ & $\begin{array}{l}\text { Symbol and othak athik mathuk which depicts five human characteristics, the } \\
\text { characteristic of human attraction toward fellow human, human desire, good passion as } \\
\text { the manifestation of God's entity within human, as well as the human's character } \\
\text { which is adjusted based on the surround environment. }\end{array}$ \\
\hline
\end{tabular}

The Local Wisdom in Javanese Thinking Culture ... (Fitriana Kartika Sari) 
The researcher used document analysis technique to collect relevant data for the topic or problem studied. The data were collected from textbooks, research reports, rules, laws, kaleidoscope, encyclopedia, and either printed or non printed resources to find basic theories of the study and collect data and facts to support researcher's argument. Sugiyono (2016: 82) stated that document is a record of past events. Those records can be in form of writing, picture, or someone's monumental works. During the data collection process, there were three phases of activities taken place as stated by Miles and Huberman (2014: 16), i.e. data reduction, data display, and conclusion drawing or verifying.

\section{RESULT AND DISCUSSION Result}

Hanacaraka is the term that refers to the Javanese written inscripture, Javanese script. The term is taken from on the sequential order of the twenty Javanese scripts which is started from the five first letter of the script hanacaraka. Javanese scripts function mainly as the documentary means of a phenomenon. As stated by Riyadi (in Ahmadi, 2002: 94), hanacaraka's main function is related to the written record of teaching, concepts, and ideas, to create written document such as inscriptions, charters, manuscripts, articles, books, and letter. Moreover, Javanese script has loaded with philosophical meaning that the Javanese writers and/or poets try to reveal through philosophical culture. One of the literary works that reveals the philosophical meaning of Javanese script is Serrat Kérata Basa. Serat refers to the classic literay works in the form of manuscript which was written by the Javanese writers and/or poets through maximum contemplation and investigation of human common senses. Sulaksono (2014: 6) stated that serat, created by Javanese writers and/or poets, is the sources or reference to study Javanese philosophy. If we closely study them, the sources are the real form of Javanese local wisdom .

The findings on the local wisdom of Javanese thinking culture within the exposure of hanacaraka philosophy in Serat Kérata Basa were summed up in the following Table 1.

\section{Discussion}

The local wisdom in Javanese thinking culture within hanacaraka philosophy discovered by researchers are othak-athik mathuk thinking culture and symbolism culture. The othak-athik mathuk culture thinking culture is widely used by Javanese people in their daily lives. Suwardi (1996: 133) said in his research that othak-athik mathuk thinking culture has become entrenched in Javanese society so that it is not impossible if it also inspires the interpretation of Javanese script. Othak-athik mathuk consists of the teaching to always think creatively, logically, smartly, and sensitively to all existed phenomena. Suwardi (1996: 83) also states that process of interpreting Javanese script philosophy based on othak-athik mathuk is based on contextual semantic interpretation, logic believed to be true, and harmony. The condition of Javanese script is also not rigid so that it gives loose interpretation space.

Othak-athik mathuk thinking culture and symbolism culture of the ha script depicts the characteristic of human who own high luck; those who have ear patterns as the $h a$ script writing and those who have $h a$ scripts on their name. Othak-athik mathuk of the ha script symbolize five human senses and five requirements that should present on the great court with the king (pancaniti). Those analogy 
concludes that those who have ear patterns as the $h a$ script writing and those who have $h a$ scripts on their name own high luck. Pancaniti means the king's throne during great court (palênggahaning ratu yèn pinuju rêrêmbugan) (Baoésastra Djawa, 1939: 466). Pancaniti is a standardized ritual and should present in the palace's life. The term niti according to Baoésastra Djawa (1939: 346) also means ritual (pranatan). The use of king's symbolism refers to symbolize happiness. King in Baoésastra Djawa means king, ruler (raja, pangarêp) (1939: 522). The position of the king as the leader of the country also symbolizes the highest position. Thus, happiness becomes the most dominant common senses that control the entire body and mind system. The use of vizier (patih) symbolizes kindness. General in Baoésastra Djawa refers to the noble warrior who performs services for the country and accomplishes the king's order (priyagung kang nindakaké paprèntahaning nêgara utawa êmbaning ratu) (1939: 476). Vizier (patih) can also refer to the most trustworthy person of a king in running the country. $\mathrm{He}$ is also frequently asked for any suggestions of governance problems. It shows that human's logic is more dominant for the pursuit of happiness, yet kindness should also base for any of those acts. The use of the priest (brahmana) symbol refers to the symbol of wirya atau nobility. The priest (brahmana) in Baoésastra Djawa refers to the religious status of a person (golonganing pêndhita) (1939: 58). In Hindu kingdom era, the priest (brahmana) was the highest caste/social position that was highly-respected by the king and nobles. Thus shows that to pursue earthly pleasure, human should always remember their religion with all the rules that should be obeyed. When a human can obey all the religious' laws and put God in all efforts, he will gain earthly and divine nobility. Judge in Baoésastra Djawa means officer who decide a particular problem (juru ngadhili pêrkara) (1939: 78). The use of judge symbol refers to brana or wealth symbols (Baoésastra Djawa, 1939: 59). Wealth frequently use tomediate the problems. The wealth also gives power to human from the problem they face. General (Sénapati) in Baoésastra Djawa means the leader of the warrior (lêlurahing prajurit) (1939: 556) or similar to the warlords. The use of General (Sénapati) symbol refers to manggya which means nêmu or discovers (Baoésastra Djawa, 1939: 293). The warlord's should be able to solve the problems within the war. It shows that human always needs new inventions to make his life easy and complete all the achievements in life.

Othak-athik mathuk thinking culture and symbolism culture of the $n a$ script depicts five stages of human development during pregnancy which symbolized though the radiance of five gems. Human is the noblest creatures. Sada (2016: 133) said in his research that human is the most respected and given most benefits by Allah than His other creatures. With the benefits of their senses, human can differentiate the bad and good, so they can choose. Allah SWT creates human as His best creation (ahsanutaqwim), and surmount the universe so human can nurture, cultivate and preserve continuity of the life in the universe. Therefore, othak-athik mathuk of the na script depicts five stages of human development during pregnancy which symbolized though the radiance of five gems, i.e. intên, mirah, campaka, nila and jumêrut. Intên in Baoésastra Djawa means the highly valued stone gems which looks like the mirror and has bright radiance (watu pêlikan kang aji bangêt wujudé kaya kaca sumorot) (1939: 171). The use of 
diamond (intên) symbol refers to white radiance, the radiance that strengthens the embryo's bones. Ruby (mirah) in Baoésastra Djawa means the red gemstone (intên abang) (1939: 317). The use of Ruby (Mirah) symbol refers to the red, the radiance that refreshes the embryo's muscle. Champak (Campaka) in Baoésastra Djawa means a type of big magnolia (bangsaning kêmbang kanthil gêdhé) (1939: 624). Magnolia has yellowish petal. The use of General (Sénapati) symbol refers to Champak (Campaka) refers to the yellow radiance, the radiance that make the embryo's skin elastic. Sapphire (Nila) in Baoésastra Djawa means blue gemstone (intên biru) (1939: 244). The use of Sapphire (Nila) symbol refers to black radiance that make the embryo's face glow or make it heart gloomy. Emerald (Jumêrut) in Baoésastra Djawa means a type of greenish gemstone (bangsa intên warnané ijo) (1939: 95). The use of emerald (jumêrut) symbol refers to the pinkish radiance, the radiance that make the embryo's hair and nail grows well.

Othak-athik mathuk thinking culture and symbolism culture of the $c a$ depict the wrath that takes control of human. This type of desire is easily adhered as the typical characteristics of the previous generation, thus parents should be careful to prepare them from now on. Othak-athik mathuk of the ca script symbolize five human conflicts (pancakara) through wrath that can be a child's character easily. Pancakara means war, fight (pêrang, kêrêngan).(Baoésastra Djawa, 1939: 466). The term pancakara in this context refers to the conflict due to the human wrath. The wraths that control human make them greedy and selfish. Due to the wrath, human gets more stimulated to win over the debate, conquer others, and take benefit of other to satisfy his greed. This type of desire is easily adhered as the typical characteristics of the previous generation, thus parents should be careful to prepare them from now on.

Othak-athik mathuk thinking culture and symbolism culture of the $r a$ script depicts the presence of God in all aspects of life, even though the creatures cannot see it directly. The creature can only feel the presence through the fate they see and undergo. Othak-athik mathuk of the interpretation of $r a$ script symbolize $k i j a b$ in (five directions) pancakumara and human fate dynamic. Kijab denotatively refers to wrana, as the cover (aling-aling) (Baoésastra Djawa, 1939: 669). The term kijab symbolizes big cover to disguise God's visual in earthly life. The cover is detonated in form of human fate dynamic. As creature, human can only feel God's presence through the fate they see and undergo, thus God's characteristics seems to be changing according to their present fate. Therefore, there are lots of premise on the authentic existence of God and questions on why there are many different fate directions in life. God really covers all kind of mystery that human must reveal.

Othak-athik mathuk thinking culture and symbolism culture of the $k a$ script describes human intelligence. Othak-athik mathuk of the $k a$ script interpretation symbolizes five human senses (pancadriya) and five characteristics of intelligent people. The vision sense refers to the sharp vision to make human alert and cautious. The smelling sense symbolizes the process of knowledge absorbent. The hearing sense symbolizes human sensitivity toward knowledge, because ears are the entrance of the surrounding sounds. The sound from surrounding environment symbolizes the new knowledge, thus the sharper the hearing sense, the more sensitive human is to the new knowledge. The tasting sense symbolizes human's sensitivity to all feelings so he/she 
can be adjust him/herself to different situation (êmpan papan). Kasnadi and Sutejo (2018: 93) explain that êmpan papan become the key to make the universe works in balance and harmony. The tasting sense symbolizes empathy. Empathy relates to intuition, so human can see other's intention or ideas by examining particular situation through empathy. People who own the characteristics as portrayed by $k a$ script will be considered as waskitha or intellegent one. They will consider as a skillfully rich people because they can feel and be grateful for God's power which mostly shown through their senses.

Othak-athik mathuk thinking culture and symbolism culture of the $d a$ script depicts five things to support life; i.e. physical body, passion or desire, breath, soul, and energy. Othak-athik mathuk of the $d a$ script interpretation symbolizes five element of life sources and five means of human life. Earth symbolizes one of the important elements of life, the physical body. Serrat Kakiyasaning Pangracutan (Riyadi, 1981: 92) stated that God creates fire, soil, wind, and water to become all parts of human characteristics. Soil which is transformed into physical body signifies four things; i.e. skin, flesh, bone, and marrow. Fire symbolizes one of the sources of life; i.e. passion or desire. Sêrat Kakiyasaning Pangracutan (Riyadi, 1981: 20) stated that fire transforms passion into desire and marks four desires; symbolized through red, black, yellow, and white radiances. Passion or desire can highly motivate people to live their life and make their dreams come true. Wind symbolizes an element of life sources; breath. Riyadi (1981: 2) explained that wind or air is transformed into breath; the breath from mouth, nose, eyes, and ears. Next, water symbolizes an element of life sources; soul. (Riyadi, 1981: 20) explain that water is transformed into soul. Human who realize the predetermination of those five life elements will gain much unbelievable luck.

Othak-athik mathuk thinking culture and symbolism culture of the ta scrpt depicts human compliance to accept five God's fate, i.e. drawback, shame, discomfort, trial, and deadlock. Othak-athik mathuk of the ta script interpretation symbolizes five guts (pancasura and five human compliances to accept God's ill fate. In Baoésastra Djawa, panca means five (1939: 466) and sura means guts, bravery (kêndêl, wani) (1939: 575). Pancasura symbolizes five guts to accept God's ill fate. The compliance of being poor (Purun mlarat) symbolizes the compliance to accept drawbacks. Purun in Baoésastra Djawa means willing,eager (gêlêm, wani ) (1939: 504). Purun symbolizes complience toward one things; purun in this context symbolizes compliance characters (nrima) to accept God's fate. Also, the compliance to accept shame (purun wirang) can be symbolized as the willingness to accept dishonor. the compliance to accept hunger (purun lapa) can be symbolized as the willingness to act simple life (laku prihatin) through fasting, the compliance to accept grieves (purun sakit) can be symbolized as the willingness to accept life trials keenly and devotedly, and the compliance to accept death (purun pêjah) can be symbolized as the willingness to accept deadlock or being stopped.

Othak-athik mathuk thinking culture and symbolism culture of the $s a$ script depicts the lack of five elements of humanities. Beyond all of the privileges given by God, human also have lots of weaknesses. Othak-athik mathuk of the $s a$ script interpretation symbolizes the degeneration of human senses' function due to human;s weaknessess. Lacking of vision (Sudaning paningal) symbolizes the lack of 
caution. Lacking of hearing (Sudaning pamirêng) symbolizes the lack of knowledge sensitivity. Lacking of tasting (Sudaning pamiraos) symbolizes ignorance. Lacking of body's vitality (Sudaning badan) symbolizes body's vulnerability (get sick easily). Lacking of muscular strength (Sudaning otot) symbolizes helplessness. Those five become the signs for human to always be careful to gain good end in life; e.g. having nobility and entering the heaven.

Othak-athik mathuk thinking culture and symbolism culture of the wa script depicts the acts conducted by human to abolish suffering. Othak-athik mathuk of the wa script interpretation symbolizes pancawara, the acts conducted by human to abolish suffering. Pancawara means (the spells to make easy labor delivery and so forth) japa mantra dianggo nyranani murih énggalé lairing jabang bayi, lan sapanunggalané (Baoésastra Djawa, 1939: 466). Thus, means (sarana) are related to things or services that can be used to overcome the problem. Spells (Mantra) are related to the symbols of praying act sebagai. The spells basically contains prayers and hopes to achive human's goal. As Hartarta (2010: 1) said that spells (mantra) are Indonesia' cultural product in the form of literary rhyme of words collection which have magical streght, spoken as the emphasis of particular goals, and created as the innovation to overcome social problems. Spells (mantra) are taking form of spoken, written, or partly spoken. Medicine (usada) symbolizes human curative acts after getting badluck. Blow (damu) symbolizes the taking of a deep breath. Taking a deep breath is a spontaneous acts that mostly done by human to lose the life suffering temporarily. Saliva (idu) symbolizes the order given to others. Saliva refers to the words that can be used to abolish suffering. By means of saliva, human can give order to others to help abolish the present problems.

Othak-athik mathuk thinking culture and symbolism culture of the la script depicts the state of nupus. Othak-athik mathuk of the la script interpretation symbolizes the direction of wind with nupus and the journey of human spirit. Nupus symbolizes the air circulation within human body. Nupus is the type of breath which controls feelings and flows through all human senses. The journey itself iss then called as saréngat, hakékat, tarékat, and makripat. Riyadi (1981: 58) described saréngat as the journey of the air within one's body to the speech organ, hakékat as the journey of the air within one's spirit and centered on the ears, tarékat as the journey of the journey of the air within one's heart and centered on the nose, and makripat as the journey of the air within one's feelings and centered on the eyes. Nupus has precautious characteristics; warns human about the journey of their spirit to make them stay modest.

Othak-athik mathuk thinking culture and symbolism culture of the $p a$ script depicts five destructive human conditions, i.e. having negative attitude to others, having stubborn character, being insensitive and disrespectful to others, being rude, and conducting vices. Othak-athik mathuk of the pa script interpretation symbolizes organs deformity with human circumstances that result on their own lost. Vision deformity (Cacad paningal ') symbolizes the people who always having negative attitude to others. Hearing deformity (cacad pamiyarsa) symbolizes stubborn person. Tasting deformity (cacad pamiraos) symbolizes insensitive, numb, or disrespectful person. Body deformity (cacad badan) 'cacat tubuh' symbolizes person who likes to use harms. Attitude deformity (cacad ing solah) symbolizes person who conducts vices. People 
who own those five deformity have disappointing characters.

Othak-athik mathuk thinking culture and symbolism culture of the dha describe creation (cipta) derived from all driven attributes called as napas, anpas, tannapas, nupus. Othak-athik mathuk of the dha script interpretation symbolizes pancawedha with human creation (cipta). Pancawédha symbolizes five authentic knowledge in human life. In Baoésastra Djawa, panca means five (lima) (1939: 466) and wédha means learn, knowledge (ngélmu, kawruh) (1939: 658). Creation is not only ideas or inspiration, but rather refers to the ability of mind to do innovation and creative thought. Creation derives from the drive of all senses regarded as napas, anpas, tannapas, nupus. Napas is the air which controls body. Napas is existed in the pure heart. Anpas is the air which controls soul. Anpas is existed in the liver. Tannapas is the air which controls passion. Tannapas is existed in the belly button. Nupus is the air which controls feeling, as well as the key of the soul. Nupus is existed in the heart. When all of the creation (cipta) unifies, it is then God's characters become concrete.

Othak-athik mathuk thinking culture and symbolism culture of the $j a$ script depicts five human desires which put human into conflict. Othak-athik mathuk of the ja script interpretation symbolizes the pancabakah with five human desires which put human into conflict. Pancabakah in Baoésastra Djawa (1939: 466) means fight, brawl (pasulayan, kêrêngan). Conflicts for all form products derives from fertile soil (parbutan asiling bumi sadaya ) symbolizes lawwamah, a kind of desire that makes people careless. Conflicts derived from all form of wealth (parbutan asal saking sêsotya sêdaya ') symbolizes amarah, a kind of desire that makes people get in rage easily and become greedy a kind of desire that makes people. Conflicts derived from women (parbutan asal saking èstri ) symbolizes supiyah, a kind of sexual desire (lust). Conflicts derived from knowledge (parbutan kawruh ngèlmi makripat ) symbolize muthmainnah, a kind of good desire that drives human to pursue ambience in life to achieve purity. Conflicts derived from knowledge superiority (parbutan ungguling pangawikan) symbolize mardhiah, a kind of human desire to beautify life and religious value to get God's approval. Human will always be involved in the conflict to fulfill all of their desires. Related to these desires, Suprayitno (2018: 546) argues that human beings are essentially capable of living with good desires and bad desires. But the existence of bad desires must be controlled so as not to cause disruption of social life.

Othak-athik mathuk thinking culture and symbolism culture of the $y a$ decribes five kinds of human desires which put human into conflict, such as lawwamah, amarah, supiyah, muthmainnah, and mulhamah. Othak-athik mathuk of the ya script interpretation symbolizes pancamaya into five kinds of human desires. In Baoésastra Djawa, panca means lima 'lima'(1939) and maya means imaginary (sêmu),or shadow (wêwayangan). Hence, pancamaya is the symbol of five radiances. Black (cêmêng) symbolizes lawwamah. Sulaksono (2014: 25) stated that black radiance symbolizes lawwamah. Lawwamah is a kind of desire that make human unaware. Sutardjo (2008: 81) also stated that lawwamah makes human lost their attentiveness. Red (abrit) symbolizes wrath. Sutardjo (2008: 81) stated that red radiance symbolizes human's wrath. Wrath (amarah) is a kind of desire which make people greedy on everything. Sulaksono (2014: 24) said that 
wrath (amarah) makes people angry easily and be able to fulfill all of their wishes. Yellow (jênar) symbolizes supiyah. Sutardjo (2008: 81) said that yellow radiance symbolizes supiyah. Supiyah is a kind of sexual desire (lust). As stated by Sulaksono (2014: 26) that supiyah is a kind of desire which put sexual desire into priority. White (pêthak) symbolizes muthmainnah or righteousness, the purity of heart. As stated by Sutardjo (2008: 81), the white radiance symbolizes muthmainnah. Sutardjo (2008: 150) further explained that muthmainnah is the source of all virtues and resource to find Allah. Colorful radiance (mancawarni) symbolizes the mixture of various color into one, it also symbolizes the mixture of vice and virtues. Mulhamah is the desire which placed on the centre of vice and virtue as stated by Sutardjo (2008: 152). He stated that mulhamah is the desire which placed in the centre as the mental or spiritual consideration.

Othak-athik mathuk thinking culture and symbolism culture of the nya describes five things that become the source of the obstructions. Othak-athik mathuk of the nya script interpretation symbolizes pancabaya ( the sharp things (lêlandhêp), fangs (siyung), stings (êntup), poison (upas), venom (wisa), disaster (rancana), panic attack (Gugup kagèt) with five sources of obstructions. Lêlandhêp symbolizes sharp. Fangs (siyung) or stings (êntup) are animals' weapon to attack their enemy when they feel threatened. Therefore, fangs (siyung) symbolizes as tools to attack others. Poison (upas) is the substances that damage enzym and can be considered as the symbol of destruction act. Rancana in Baoésastra Djawa(1939: 519) means disaster, allure (bêncana, godha), it symbolizes bad destiny. Panic attack (Gugup kagèt) is an uncontrollable surprised feeling due to spontaneous circumstances. Panic attack (Gugup kagèt) symbolizes uncontrolled emotion. Hence, human must always be aware and believe to God so they can avoid disasters.

Othak-athik mathuk thinking culture and symbolism culture of the ma script depicts five human desires, such as mutmainnah, amarah, supiyah, radhiah, and mardhiah. Othak-athik mathuk of the ma script interpretation symbolizes pancabayu with five human desires. Pancabayu symbolizes five Bathara Bayu sons. In Baoésastra Djawa, panca means five (lima) (1939: 466), and bayu means wind. In Javanese tradition, Bayu is the name of god who rules the wind Bathara Bayu. Bathara Bayu's son from the white apes' tribe is Anoman who symbolizes mutmainah. Bathara Bayu's son from giant tribes is Wrêka who symbolizes amarah. Bathara Bayu's son from fish tribes is Satubanda who symbolizes supiyah. Bathara Bayu's son from human tribes is Bima who symbolizes radhiah. Bathara Bayu's son from mountain tribes is Parasu Mountain who symbolizes mardhiah. mutmainnah yis the good desire that start the drive for heart purity. Amarah, is the source of wrath that make human do sins and outlaw acts. Supiyah is the type of desire that to prioritize sexual drive. Radhiah is the desire to look for Allah's approval. Mardhiah is the desire to be persistent in doing the principal values in life. When human desires go alongside persistency, the human with bad characteristic will become worse, but those who are good will get better.

Othak-athik mathuk thinking culture and symbolism culture of the $g a$ scripts depicts five things that abrupt human peacefulness. Othak-athik mathuk of the ga script interpretation symbolizes prejudices (pancatnyana) along with five disruptions of human peacefulness. The anxiousness which is 
derived from the skeptism (maras saking panyana) symbolizes the mental illnesses. The anxiousness which is derived from the suspicion (maras saking panggagas) symbolizes narrow mindset. The anxiousness which is derived from the helplessness (msaking émar) symbolizes the insecure feeling. The anxiousness which is derived from doubt (maras saking sêmang-sêmang) symbolizes the lost of persistency. The anxiousness which is derived from fear (maras saking ajrih) symbolizes the vulnerable faith. Anxiousness drives human to mature the soul to vanish the continual appearances of anxiety.

Othak-athik mathuk thinking culture and symbolism culture of the $b a$ script depicts five essences of human visions. Othak-athik mathuk of the $b a$ script interpretation symbolizes five human visions (pancapramana) alongside five essences of human visions. Eyes (Paningal) symbolize the visual sharpness to see invisible objects. Pandulu symbolizes the universality of vision, the ability to see universe and natural dimension which consists of visible and invisible being. Pandêlêng symbolizes visions' accuracy, the ability to see particular object accurately, not just regular seeing. Uninga symbolizes the sharpness of inner eye, the ability to see and understand hidden things. Pangaksi symbolizes direct witnessing, the activity to one things or events by one's own eyes. People who have those essences of vision can optimize all the visions they have to see either visible or invisible object clearly.

Othak-athik mathuk thinking culture and symbolism culture of the tha script depicts five human desires, amarah, lawwamah, supiyah, muthmainnah, mulhamah. Othak-athik mathuk of the tha script interpretation symbolizes five desires (pancagati), which are driven from five different colors, with five human desires (yang ditarik dari lima warna yang berbeda). Nêpsu arda is the desire which is derived from red radiances (cahya abrit). Red radiances symbolize the wrath. Sulaksono (2014: 24) stated that red radiance symbolize human desire, wrath which makes people get angry easily and be able to fulfill all of their will. Nêpsu wéya is the desire which derived from the black radiance (cahya cêmêng). Wéya means careless, clumsy (kurang wêwéka, sêmbrana) (Baoésastra Djawa, 1939: 659). Black radiance symbolizes lawwamah. Sutardjo (2008: 81) stated that black radiance symbolizes human desire, lawwamah. Lawwamah brings clumsy attitude. Nêpsu warga is a kind of desire which derived from yellow radiance (cahya jênar). Warga means types, kinds, family (gêgolongan, jinis, sanak-sedulur) (Baoésastra Djawa, 1939: 656). Yellow radiance symbolizes supiyah. Sutardjo (2008: 81) stated yellow radiance symbolize supiyah. Human desire toward their own kinds is reflected into love and sexual desire. Nêpsu dyatmika is the desire which derived from white radiance (cahya pêthak). Dyatmika means always be wellmannered (jatmika, yaiku tansah nganggo trapsila) (Baoésastra Djawa, 1939: 18). Related to the meaning of white radiance, Sutardjo (2008: 81) stated that white radiance symbolizes muthmainnah, the kind of desire that makes human have pure heart and do good deeds based on the well-mannered acts. Nêpsu réwa is the desire which derives from five-color radiance (cahya mancawarni). Réwa means imitate, impersonate (api-api, atindak kaya) (Baoésastra Djawa, 1939: 329). Five-color radiance symbolizes mulhamah. Sutardjo (2008: 152) stated that five-color radiance symbolizes human desire, mulhamah, the kinds of desire that is placed on the centre and become the mental and physical consideration. mulhamah turns people into doubt and easily affected by the present situations. 
Othak-athik mathuk thinking culture and symbolism culture of the nga script depicts five human characteristics, the characteristic of human attraction toward fellow human, human characters which fully equipped by desire, good passion as the manifestation of God's entity within human, as well as the human's character which can be changed on the basis of surrounded environment. As stated by Suprayitno (2018: 546) in his research that essentially all humans are good, but the environment and other factors shape it to be good or bad. Othak-athik mathuk of the nga script interpretation symbolizes pancajaya (five characters) with the five human characteristics. Sipat warga symbolizes the attraction of human toward the opposite sex of their own kind. Sipat kawula symbolizes the human characteristics which fully equipped with desire. Sipattullah symbolizes the good human desire. Sipat jati symbolizes panca purwanda, five things which are related to the characteristics in human elements. Endraswara (2014: 128) explained that panca purwanda is five things which are related to the characteristics in human elements; sun, earth, wind, sea, and sky characteristics. Those symbolize the manifestation of Divine characteristics within human being. The characteristics are caring or nurturing, filled or able to be filled, loaded, stuffed (among, amot, kamot, momot, mêngku) 'menjaga atau mengasuh, dapat diisi atau dapat diberi muatan, termuat, serba muat, menguasai'. Those five characteristics produce five personalities: alert, not envy, careful, compliance, persistent (ora samar, ora dhawèn, ora sêmbrana, ora kawalêsan, ora gimiran) 'tidak was-was, tidak iri, tidak ceroboh, tanpa pamrih atau ikhlas, tidak mudah tergoda'. Sipat ngam symbolizes as human personalities that always affected by the environment.

\section{CONCLUSION}

This research concludes that hanacaraka philosophical meaning is derived from Javanese local thinking culture othak-athik mathuk and symbolism. Hanacaraka philosophy is one of the ideas that can be used for wise words (pitutur luhur) and guidance to address various phenomena that occur in the future. In summary, the thinking culture othak-athik mathuk and symbolism in hanacaraka scripts depicts God creature's (human) circumstances, which is equipped with creation, feeling, and effort. Creation is the ability of the mind to create something new and creative to realize happiness, goodness, glory, wealth, and innovative discoveries that benefit life. Feeling can be understood through the five senses. Effort is shown by the fact that humans always have the will. If the will cannot be controlled, then humans are controlled by lust which causes the appearance of greed, wanting to win alone. Humans also have the will of things related to God and the authenticity of life. This triggers the human will to solve the mystery of God and the perfection of life.

The thinking culture othak-athik mathuk and symbolism in datasawala scripts illustrates that human cannot avoid all God's fate upon them until the end of their life. God's determination for human beings in the form of destiny which includes good destiny and bad destiny. Good destiny is realized in the form of life opportunities by providing various means of life. Bad destiny is a decrease in physical and mental condition of humans and tests. Humans can only accept and live it with gratitude.

The thinking culture othak-athik mathuk and symbolism in padhajayanya scripts depicts the human conditions that achieve life harmony due to the ability to unify the manifestation of 
God and human characteristics, which heats up within themselves. Humans are dominated by human characteristics that is vulnerable to negative things. But humans also have a manifestation of God's characteristics in the form of good craracteristics. Both of these characteristics have a strong influence. If humans are able to harmonize the two characteristics, he will achieve harmony of life. The thinking culture othak-athik mathuk and symbolism in magabathanga scripts describes the human condition which put God's order highly by doing all the orders and avoiding all of His warnings. God commands humans to have courage, soul maturity, vigilance and selfawareness.

\section{REFERENCES}

Ahmadi, M. (2002). Dari Hana Caraka Ke Sastra Macapat dan Suluk (Hubungan Sastra Lisan dan Tulis). Prosiding Seminar Akademik 2, 2002: 89-103. Malang: Fakultas Sastra Universitas Negeri Malang

Anonim. (1895). Serat Kerata Basa. Surakarta: Museum Radyapustaka.

Ardani, M. H. (1994). Makna Ha-na-ca-raka; Tinjauan dari Segi Filsafat Sufisme. Yogyakarta: Balai Kajian Jarahnitra dan Lembaga Javanologi Panunggalan.

Awalin, F. R. N. (2017). Dunia Batin Jawa: Aksara Jawa Sebagai Filosofi dalam Memahami Konsep Ketuhanan. Kontemplasi, 5 (2), 289-309.

Darusuprapta.(1994). Pengkajian Hanacaraka dari Segi Sastra. Yogyakarta: Balai Kajian Jarahnitra dan Lembaga Javanologi Panunggalan.

Ekowati, V.I. (2012, 29-30 November). Javanese Letters: Symbols Of Javanese Civilization: (Introduction, History,
Philosophical Values, Learning Methods, Utilizations, to Uch Of Technology In Javanese Letters). Paper presented at $1^{s t}$ Mae Fah Luang University International Conference Mae Fah Luang University, Thailand.

Endraswara, S. (2016). Falsafah Hidup Jawa. Yogyakarta: Cakrawala.

Gie, T. L. (2012). Pengantar Filsafat Ilmu. Yogyakarta: Penerbit Liberty.

Hartarta, A. (2010). Mantra Pengasihan Rahasia Asmara dalam "Klenik” Jawa. Yogyakarta: Kreasi Wacana.

Herusatoto, B. (2008). Simbolisme Jawa. Yogyakarta: Penerbit Ombak.

Kasnadi, Sutejo. (2018, 18 Juli). Traditional Javanese Idioms as The Representatives of The Society's Character. Paper presented at The $1^{\text {st }}$ International Conference on Education Language and Literature (Icon-Elite) 2018, State University of Surabaya, Surabaya.

Miles, M. B., \& Huberman, A. (2014). Analisis Data Kualitatif: Buku Sumber Tentang Metode-metode Baru. Jakarta: Penerbit Universitas Indonesia (UI Press).

Poerwadarminta, W. J. S. (1939). Baoesastra Djawa. Batavia: J.B. Wolter's Uitgevers=Maatschappij.

Rais, W.A. (2017). Kearifan Lokal dalam Bahasa dan Budaya Jawa: Studi Kasus Masyarakat Nelayan di Pesisir Selatan Kebumen Jawa Tengah (Kajian Etnolinguistik). Surakarta: UNS Press.

Riyadi, S. (2005). Filsafat Ha-Na-Ca-Ra-Ka. Widyaparwa, 33 (1), 73-89.

Sada, H.J. (2016). Manusia dalam Perspektif Agama Islam. Al-Tadzkiyyah: Jurnal Pendidikan Islam, 7 (1),129-142.

Sari, F.K., Supana., Suwandi, S. (2017, 2 Mei). Nilai Ketuhanan dalam Makna Filosofis 
Aksara Jawa sebagai Upaya Penguatan Karakter Siswa di Era Teknologi Informasi. Paper presented at National Education Seminar, Faculty of Language and Art State University of Semarang, Semarang.

Sugiyono. (2016). Memahami Penelitian Kualitatif. Bandung: CV Alfabeta.

Sulaksono, D. (2014). Filsafat Jawa. Surakarta: Cakrawala Media.

Supadjar, D. (1994). Ha na ca ra ka Pemahaman Total Integral Makna Kehidupan. Yogyakarta: Balai Kajian Jarahnitra dan Lembaga Javanologi Panunggalan.
Suprayitno, E., Rois, S., Harmanto, B., \& Iman, N. (2018, 2 Agustus). Moralitas Jawa dalam Cerita Rakyat Raden Bathoro Katong dan Ki Ageng Kutu Surya Ngalam di Kabupaten Ponorogo. Paper presented at National Seminar and Multidisciplinary Panel Discussion on Research and Community Service Results, Indraprasta PGRI University, Jakarta.

Sutardjo, I. (2008). Kajian Budaya Jawa. Surakarta: Penerbit Jurusan Sastra Daerah Fakultas Sastra dan Seni Rupa Universitas Sebelas Maret.

Suwardi. (1996). Cakrawala Pendidikan, XV (2), 83-94. 